\title{
Biosaintifika
}

Journal of Biology \& Biology Education

http://journal.unnes.ac.id/nju/index.php/biosaintifika

\section{Moleculer Detection of Protozoa Trichodina spp. In Gourami (Osphromenus Gourame Lac.) Larvae with The infecting 18S rRNA Gene Marking in Exs. Residence of Banyumas, Central Java}

\author{
${ }^{\otimes}$ Rokhmani, Endang Ariyani Setyowati, Daniel Joko Wahyono \\ DOI: http://dx.doi.org/10.15294/biosaintifika.v10i2.11720 \\ Faculty of Biology, Universitas Jenderal Soedirman, Indonesia
}

\section{History Article}

Received 28 October 2017

Approved 24 January 2018

Published 30 August 2018

\section{Keywords}

Banyumas; Detection; Gourami; Molecular; T. Heterodentata

\begin{abstract}
Protozoa species of Trichodina spp. may be found in most hatchery centers in Banyumas, Purbalingga, and Banjarnegara. However, the determination of Trichodina spp. types is still based on its body's morphological variations, not yet molecular. A research has been conducted to identify molekuler of the Trichodina spp. with the infecting 18S rRNA gene marking on the gourami larvae in Exs. Residence of Banyumas, Central Java. The research used a survey method with the samples of gourami. Amplification of $18 \mathrm{~S}$ rRNA gene from Trichodina heterodentata was Performed using PCR technique. Primer used is Forward primer (5'-AAC CTG GTT GAT CCT GCC ATG-3') and Reverse primer (5 '-TGA TCC TTC TGC AGG TTC ACC TAC-3') which produces a $600 \mathrm{pb}$ amplicon of DNA. Molecular research can be a complementary identification of organisms morphologically. Amplification of the partial $18 \mathrm{~S}$ rRNA gene may be used to identify Trichodina specifically. Gourami larvae taken from the hatchery centers in Banyumas, Purbalingga, and Banjarnegara. The results show that the detected percentage of Trichodina heterodentata genes with the infecting 18S rRNA gene marking on the gourami larvae in Central Java taken from the hatchery centers in Banyumas, Purbalingga and Banjarnegara are respectively $10 \%, 10 \%$, and $45 \%$. This research provides a benefit in mapping the presence of protozoa pathogen of Trichodina spp. in gourami hatcheries in the Former Exs. Residence of Banyumas, Central Java
\end{abstract}

\section{How to Cite}

Rokhmani, Setyowati, E. A., \& Wahyono, D. J. (2018). Moleculer Detection of Protozoa Trichodina spp. In Gourami (Osphromenus Gourame Lac.) Larvae with The infecting 18S rRNA Gene Marking in Exs. Residence of Banyumas, Central Java. Biosaintifika: Journal of Biology \& Biology Education, 10(2), 320-325.

(C) 2018 Universitas Negeri Semarang
Correspondence Author:

J1. Dr. Soeparno 63, Purwokerto, Banyumas 53122, Central Java, Indonesia

E-mail: rokhmanitatiek@gmail.com
p-ISSN 2085-191X e-ISSN 2338-7610 


\section{INTRODUCTION}

Gourami (Osphronemus gourami Lacepede) is one fish commodity of important fresh water fisheries and has been widely cultivated in many regions in Indonesia. The above notion occurs because gourami fish has a rather high price and a great opportunity in the market. Central Java Province is a gourami larvae center that annual production increases from 94.6 tons in 2011 to 109.7 tons in 2012 ( Fisheries and Marine Office in Central Java, 2013). The above production has made gourami cultivation a very promising cultivation business. However, there are many factors affecting the growth of gourami, such as body size and parasite infection. Nuryanto et al. (2017) reported that there were genetic variations in the body size of gourami. Rokhmani et al. (2017) reported that the prevalence of Trichodina sp. infection can be as high as $100 \%$ in Bantul, Jogjakarta.

On parasite infecting the gourami larvae in all regions of gourami larvae centers is Trichodina sp. which mostly has a characteristic of pathogen, a protozoan parasite which has a cilia as its ectoparasite to infect fish skins and gills, for bothfresh water and salt water fish. This parasite multiplies by splitting itself, a process that takes place within the host body, swims freely well, able to detach itself from the host, and the body is supported by a correlated rigid disc ring called chitinoid (Durborow, 2003). Fish can also feel stressful and gets hyperplasia on its scale and receives damage on its gill structure. The Trichodina heterodentata species infecting gouramilarvae in the hatchery centers in Banyumas, Purbalingga and Banjarnega$\mathrm{ra}$, is identified based on its body measurement or morphometrics variation (Rokhmani et al., 2015) that Trichodina sp. species found in gourami larvae in Banyumas, Banjarnegara and Purbalingga are Trichodina nobilis, Trichodina reticulata. Tichodina acuta, Trichodina heterodentata, Trichodina magna, Trichodina pediculus, and Trichodina nigra. A research conducted by Rokhmani et al. (2017) also found that Trichodina heterodentata species infects gourami larvae in the hatchery centers in several cities in Java Island.

Determination of the above species organism was conducted by measuring the variation of its body morphology. There are still a lot of shortcomings and mistake in measuring organism using morphology variation. Determination of certain species develops into an important notion for the sake of diagnoses and controlling effort. Polymerase Chain Reaction (PCR) is a method to diagnose a certain microorganism validity determination as an extension to control.
Several methods to identify protozoa species are polymerase chain reaction-restriction fragment length polymorphism (PCR-RFLP), sequencing from ribosomal DNA ( $\mathrm{rDNA}$ ), internal transcribed spacers (ITS-1 and ITS-2), 5.8S rDNA (riboprinting), and mtDNA ox2 gene markers. Detection determination molecularly of a certain species based on its gen content is still rarely conducted. The previous studies for example still use the 18S $r$ RNA gene marking. A marking is the smallest unit of a reduction result from methylation or RNA cutting. Other smallest units are r RNA 5.8S, r RNA 28S. Determination detection of Trichodina spp. in Indonesia is still rare or yet to be implemented. This is because determination of DNA (Deoxyribo Nucleotide Acid) has an important role or contribution.

DNA amplification in vitro. The $18 \mathrm{~S}$ rRNA gene is often used for phylogenetic studies because it has a conserved area, and the nucleotide base data of the 18S rRNA gene allows it to be used to show the genealogical closeness to the kinship of a particular organism species. DNA is a fundamental genetic material which controls the characteristics of living creatures, expressed in polipeptida form, even though not all of it is protein (may be expressed as RNA that has catalytic reaction). Based on above explanations, we suggest an inquiry if there is Trichodina heterodentata with molecular detection on 18S rRNA gene marking which infects gourami larvae in local regions, such as those in the Former Residence of Banyumas, Central Java. The objective of this research is to detect the molecular Gene Trichodina heterodentata with $18 \mathrm{~S}$ rRNA gene marking which infects gourami larvae in local regions, such as Residence Banyumas, Central Java.

\section{METHODS}

The initial research uses a survey method, while the data are collected using a random sampling. Trichodina spp. was obtained from the isolation and identification with method preparations of organ ranges on gourami larvae. Gourami larvae centers in: Kutasari Village, Baturaden Sub-District, Banyumas Regency; Luwung Village, Rakit Sub-District, Banjarnegara Regency: Kutasari Village, Kutasari Sub-District, Purbalingga Regency. The second phaseis in addition to the molecular determination to figure out the genetic features of Trichodina spp. in various centers of gourami larvae cultivations, for exs Resident, Banyumas, Central Java. 


\section{The DNA Extraction}

The isolated Trichodina spp. from a larvae center in Banyumas, Purbalingga, and Banjarnegara is stored in a cup as well as the $\mathrm{NaCl}$ fluid. Before making an observation on genetical variation and genetical distance, isolation of Trichodina spp. is conducted on DNAgenome isolation using an alkaline lysis method. Usinga sterile pipete, 10 individual isolates of Trichodina spp. From organ preparation the gourami larvae cultivation centers level 1 , insert them into ependorf tube containing $180 \mu \mathrm{STE}$. Next, crush isolate Trichodina spp. using a sterile pipette. Add $20 \mu \mathrm{l}$ proteinase $\mathrm{K}$ and $200 \mu \mathrm{l}$ buffer (bufferlysis) to the sample. Next, at the vortex, evenly mix and incubate at $70 \mathrm{C}$ for 10 minutes with box heater, add $200 \mu \mathrm{l}$ etanol $100 \%$ to each sample and revortext denaturalize the proteinase $\mathrm{K}$. Aspirate the solution mixture with a pipette and insert into Dneasy spincolumn tube and then centrifuge at 8,000 rpm for 1 minute. Remove the solution passing the spincolum and transfer to a new 2 $\mathrm{ml}$ tube and then wash with $500 \mu \mathrm{l}$ buffer AW2, then centrifuge at $16,000 \mathrm{rpm}$ for 3 minutes to dry the Dneasy membrane. Re-remove the solution and pipe collection. Put Dnea sycolumn in sterilized micro centrifuge and add $200 \mu \mathrm{l}$ buffer $\mathrm{AE}$ with a pipette directly on the membrane. Centrifuge the sample for 1 minuteat 8,000rpm. Remove the Dneasy spincolumn and keep the solution at-20 Celcius for the next test. Amplify the resulted DNA withthe RAPD technique. Amplify the DNA fragment with the RAPD technique. The total volume for PCR was 10ul consisting of $5 \mathrm{ul}$ go taqgreen PCR mastermix 2x; 2.25ul DNA; $0.25 \mathrm{ul}$ prime and 2.5ul water of nuclease free. The DNAis amplified using PCR Thermal Cycler BOECO.

The primer determination on molecular parasite identification of Trichodina spp., uses the gene from Trichodina heterodentata was used is Forward primer (5'-AAC CTG GTT GAT CCT GCC ATG-3') and Reverse primer (5 '-TGA TCC TTC TGC AGG TTC ACC TAC-3’) expected bp 600 ( Tang et al., 2013 )

On electrophoresis phase, a preparation of agarose gel is weighed as needed. The agarose concentration used is $1 \%$. Using the hotplate, dilute the agarose until boiling; let it for 25 minutes until the temperature decreases to $50^{\circ} \mathrm{C}$, then cast in the agarose tray equipped with a comb to form a gel well. After cooling down the agarose, lift the tray comb up and insert the gel into electrophoresis which is already contained with TAE $1 \mathrm{x}$ as electrophoresis buffer. Immerse the gel from electrophoresis in ethidium bromide (with con- centration of $1 \mathrm{mg} / \mathrm{ml}$ ). Next, wash the gel with aquadest for 10-15 minutes. Visualize the DNAon UV transilluminator and take some Figures. Document the visualization results using a digital camera. The profile of eachprimer's DNAfragment patterns is positive and negative separately based on the presence of fragments using the binary score. Positive and negative indicate DNA isolation visualized on the agarose gel yielded 19 DNA bands of 250 - $500 \mathrm{bp}$, the entire DNA band indicates the presence of Trichodina heterodentata

The collected data are then descriptively analyzed based on the presence of DNA fragments generated from the primer of each locus. The qualitative RAPD fragmented patternis then converted into the qualitative binary.

\section{RESULT AND DISCUSSION}

Cultivation of gourami larvae on larvaean I, lasts for 1 - 2 months with seeds obtained between $3-4 \mathrm{~cm}$. At this age, less than perfect or not yet established an optimal immune system so it is still susceptible to infections parasitic disease.. Disease caused by Trichodina sp. called Trichodiniasis, which infect many at larval age and small fish or larvae (Martins et al., 2010). Variations of morphological characters Trichodina sp. indicated by differences in form variation, variation in the number and size of some body parameters (Windarto et al., 2013).

Trichodina sp. which are found in each fish body have different morphometric characters. Morphological differences are known through morphometric and meristic characters such as: body diameter, diameter of denticle ring, adhesive disc diameter, membrane width and number of dents (Dana et al., 2002). The morphometric character is the reference for determining Trichodina sp. in general is measuring the diameter of the body, diameter of the ring dentikel, adhesive disc diameter, membrane width and the number of dents. (Basson \& Van As, 1994). It also looks at the morphology of the denticles, also can be based on blade shape, ray shape, apex blade type, blade apophysis, blade connection.

Even though it is mostly found on the fish mucus, Trichodina sp. is also found in other fish's defense structure of all fish in all age and size. Zhao and Tang (2011), reports that Trichodina sp. are mostly found on the fish mucus, the epithelium tissues and blood are the best nutrition for this parasite. The infection of the Trichodina sp. were mostly intheir gills, especially when they were still in juvenile stage, since this stage is the best environment for the parasite to grow. The body's 
defense structure is complemented by scales, skin and mucus products. This suggests that the type of organisms that willing to live together is only a few. Morphometric variation of Trichodina spp. to be observed is, for example, the varying forms of the denticle, which are the proximal, tapered, curved and accumulated forms of denticles. The straight-tapered denticle is in Trichodina heterodentata and Trichodina nobilis. The form of a straight but slightly collected denticle is Trichodinaacuta, while the shape of the denticle of Trichodina magna is curved. The specificity of in Trichodina magna is more curved than in Trichodina acuta, Trichodina heterodentata and Trichodina nobilis. Denticle in Trichodina heterodentata has a tapered but thicker shape, while the blade connection on Trichodina nobilis is narrower and its apophysis blade is tapered.

The results of a research the types of Trichodina sp. found in gourami larvae with morfhometric variation in Banyumas, Banjarnegara, and Purbalingga are Trichodina nobilis, Trichodina reticulata, Tichodina acuta, Trichodina heterodentata, Trichodina magna, Trichodina pediculus, and Trichodina nigra (Rokhmani et al., 2015). The conducted by Rokhmani., et. al. (2017) find that there is Trichodina heterodentata in gourami larvae in several cities in Java Island. Determination of the above species is based on descriptions or variation of its body morphometrics. In general, the morphology of Trichodina sp. shows several ray forms and varying forms of denticles. Trichodina heterodentata has blade apex end with a blunt/dull and denticle ray shape which is tapered straight but thicker.

Trichodina spp has the characteristics of adhesive disc diameter of $38-82 \mu \mathrm{m}$; denticle ring diameter of $23-51 \mu \mathrm{m}$; and number of denticles of 20-30. Trichodina heterodentata has the characteristics of body diameter 71-106 $\mu \mathrm{m}$; denticle ring 26-37 $\mu \mathrm{m}$; diameter; adhesive disc 47-63 $\mu \mathrm{m}$; number of denticles 20-27; with membrane width of $2.7 \mu \mathrm{m}$. The data according ( Rokhmani, 2015 ; Woo ,1995) Trichodina heterodentata has the characteristics of adhesive disc diameter of $38-82 \mu \mathrm{m}$; denticle ring diameter of 23-51 $\mu \mathrm{m}$; and number of denticles of 20-30. Trichodina heterodentata has the characteristics of body diameter 71-106 $\mu \mathrm{m}$; denticle ring 26-37 $\mu \mathrm{m}$; diameter; adhesive disc 47-63 $\mu \mathrm{m}$; number of denticles 20-27; with membrane width of $2.7 \mu \mathrm{m}$ ( Rokhmani, 2015). However, according in Woo (1995), The morphometric characteristic of T.heterodentata in gourami larvae. T. heterodentata is a type of cosmopolitan Trichodina, Trichodina heterodentata was first identified by Martins, et.al., (2010).
Sample from each hatchery center, the researcher takes 20 samples from Banyumas, Purbalingga, and Banjarnegara. The samples are then analyzed with primer Gene 18S rRNA from T.heterodentata with advance primer 50-AAC CTG GTT GAT CCT GCC AGT-30 and reverse primer 50-TGA TCC TTC TGC AGG TTC ACCTAC-30 (Tang, Fa-Hui , 2012). Based on the samples taken from each gourami hatchery centerin Banyumas, Purbalingga, and Banjarnegara, the treatment is analyzed in percentage that the T.heterodentata is respectively at primer bp 600 each $10 \%, 10 \%$ and $20 \%$ (Table 1 )

Table 1. The Percentage of Trichodina heterodentata Detectionwith the infecting 18S rRNA Gene Marking on the Gourami hatchery Exs. Residence Banyumas Central Java

\begin{tabular}{lccccc}
\hline S a m ple & \multicolumn{2}{c}{ Each } \\
& sample & $\begin{array}{c}\text { Positive } \\
\text { Result }\end{array}$ & \multicolumn{2}{l}{$(\%)$} \\
\hline Banyumas & 2 & 0 & 2 & 1 & 0 \\
Purbalingga & 2 & 0 & 2 & 1 & 0 \\
Banjarnegara & 2 & 0 & 9 & 4 & 5 \\
\hline
\end{tabular}

The Table 1., sample positive percent ofprotozoaTrichodina heterodenta -tarespectivelyresulted from the samples in Banyumas, Banjarnegara, and Purbalingga by $10 \%, 45 \%$, and $10 \%$. The samples in Banjarnegarapositive percent of protozoa Trichodina heterodentata, by $45 \%$ showed a high, is according the intensity of Trichodina sp. on gouramy fish larvae pond cultivation Village District Rakit Banjarnegara showed a high number. The high intensity of Trichodina sp. can be affected by several factors. According to Rustikawati (2004), the high intensity of Trichodina sp. in fish larvae is suspected because of the pool water conditions that support for the life of the ectoparasites. High intensity values can also be affected by high fish density in ponds. High density can cause fish to experience stress. In ponds with high fish density, fish will rub against each other, so that ectoparasitic infection will occur quickly. The average density of fish in ponds studied is 21-24. The high intensity of Trichodina sp. on the fish seed according because this parasite can breed quickly and always move actively.

The result of electrophoresis sample can be seen on the following illustration, enlarged at $2,000 \mathrm{bp}$ from a selected sample. At 2 sample analyzes squenzing BNJ 2 and BNJ 4 , because over $600 \mathrm{bp}$. The result of electrophoresis sample can be seen on the following illustration, enlarged at 2,000bp from a selected sample (Figure 1). 
Rokhmani, et al. / Biosaintifika 10 (2) (2018) 320-325

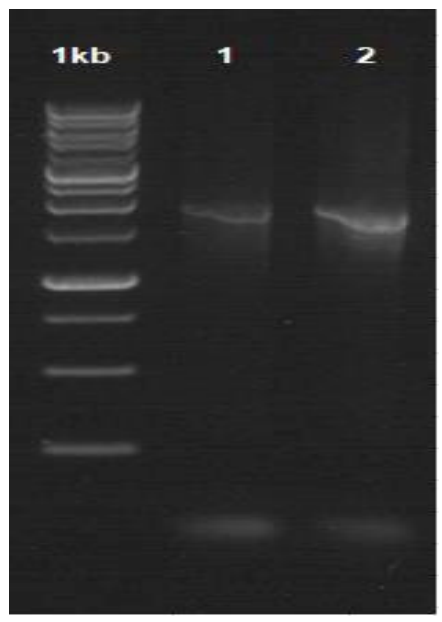

Figure 1. The Result of PCR Amplification of positive sample T. Heterodendata at 2,000 bps

The results of Figure 1 show a low rise of $T$. heterodentate concentration over $600 \mathrm{bps}$ from sample. The qualitative RAPD fragmented patternis then converted into the qualitative binary, in sample BNJ 2 ( Banjarnegara) bp 680 primer is descriptive TGCAGTCTAA GTACACACGG CCGGTACAGT GAAACTGCGA ATGGCTCATT AAATCAGTTA TGGTTCCTTT GATCGCTCTC ACGTTACTTG GATAACTGTG GCAATTCTAG AGCTAATACA TGCCAACGAG CGCTGACCTC CGGGGATGCG TGCATTTATC AGACCCAAAA CCCATGCGGG GTGCCTCTCG GGGTGCCCCG GCCGCTTTGG TGACTCTAGA TAACCTCGAG CCGATCGCTG GCCCTCGTGG CGGCGACGTC TCATTCGAAT GTCTGCCCTA TCAACTTTCG ATGGTACTTT ATGTGCCTAC CATGGTGACC ACGGGTAACG GGGAATCAGG GTTCGATTCC GGAGAGGGAG CCTGAGAAAC GGCTACCACA TCCAAGGAAG GCAGCAGGCG CGCAAATTAC CCACTCCCGA CTCGGGGAGG TAGTGACGAA AAATAACAAT ACAGGACTCT TTCGAGGCCC TGTAATTGGA ATGAGTACAC TTTAAATCCT TTAACGAGGA TCAATTGGAG GGCAAGTCTG GTGCCAGCAG CCGCGGTAAT TCCAGCTCCA ATAGCGTATC TTAAAGTTGC TGCAGTTAAA AAGCTCGTAG TTGGATCTCG GGATCGAGCT GACGGTCCGC CGCGAGGCGA GCTACCGTCT GTCCCAGCCC CTGCCTCTCG GCGCCCCCTC.

Sample BNJ 4 ( Banjarnegara) is descriptive Assembly of 2 sequences $1728 \mathrm{bp}$

TAAGTACACA CGGCCGGTAC AGTGAAACTG CGAATGGCTC ATTAAATCAG TTATGGTTCC TTTGATCGCT CTCACGT-
TAC TTGGATAACT GTGGCAATTC TAGAGCTAAT ACATGCCAAC GAGCGCTGAC CTCCGGGGAT GCGTGCATTT ATCAGACCCA AAACCCATGC GGGGTGCCTC TCGGGGTGCC CCGGCCGCTT TGGTGACTCT AGATAACCTC GAGCCGATCG CTGGCCCTCG TGGCGGCGAC GTCTCATTCG AATGTCTGCC CTATCAACTT TCGATGGTAC TTTATGTGCC TACCATGGTG ACCACGGGTA ACGGGGAATC AGGGTTCGAT TCCGGAGAGG GAGCCTGAGA AACGGCTACC ACATCCAAGG AAGGCAGCAG GCGCGCAAAT TACCCACTCC CGACTCGGGG AGGTAGTGAC GAAAAATAAC AATACAGGAC TCTTTCGAGG CCCTGTAATT GGAATGAGTA CACTTTAAAT CCTTTAACGA GGATCAATTG GAGGGCAAGT CTGGTGCCAG CAGCCGCGGT AATTCCAGCT CCAATAGCGT ATCTTAAAGT TGCTGCAGTT AAAAAGCTCG TAGTTGGATC TCGGGATCGA GCTGACGGTC CGCCGCGAGG CGAGCTACCG TCTGTCCCAG CCCCTGCCTC TCGGCGCCCC CTCGATGCTC TTAGCTGAGT GTCCCGCGGG GTCCGAAGCG TTTACTTTGA AAAAATTAGA GTGTTCAAAG CAGGCCCGGT CGCCTGAATA CCGCAGCTAG GAATAATGGA ATAGGACTCC GGTTCTATTT TGTGGGTTTT CTCTCTGAAC TGGGGCCATG ATTAAGAGGG

Next description sequencing is Trichodina heterodentata small subunit Ribosome RNA gene complete sequence, Trichodina reticulata small subunit Ribosome RNA gene complete sequence, and Trichodina nobilis 18S Ribosome RNA gene partial sequence internal transcribel spacer 1 complete sequencing and 5,8 Ribosome RNA gene partial sequenc. The result squencing according the research Martins, et.al.,( 2012)

Incidence and prevalence Trichodiniasis on gourami larvae in Exs. Recident Banyumas Central Jawa, is high incidence and prevalence. On the research Utami, S. T. ( 2015), that has been done, showed that 100 samples of gouramy fish seeds were all infected by Trichodina sp. Trichodina sp. found on the outside of the body of gouramy fish seeds. In the body of gouramy fish, Trichodina sp. can adhere to adhesion (pressure from the outside), and consume cell fluid in the mucus or contained in the epidermis. Trichodina sp. also take organic particles and bacteria when attached to the host body.

The benefits and contribution of reserch for This research provides a benefit in mapping the presence of protozoa pathogen of Trichodi- 
na spp. in gourami hatcheries in the Former and early control disease in Exs. Residence of Banyumas, Central Java.

\section{CONCLUSION}

The detection of protozoa identification in this research with primer Trichodina heterodentata resulted from the samples in Banyumas, Banjarnegara and Purbalingga shows positive percentage of containing protozoa respectively by $10 \%$, $45 \%$, and $10 \%$. The above percentage shows that Trichodina heterodentata is also found in those three Regency. Thus, this research recommends that there should be a follow-up research patogenisitas Trichodina spp. conducted early control disease on regions in Central Java.

\section{ACKNOWLEDGEMENT}

We would like to deliver our greatest gratitude, especiallyfor the Dean of Biology Faculty, as well as the head of entomology and parasitology including my staffs and students who provide assistance and contributions in this study. We would also like to thank the Head of Unsoed Reseach Centre for providing funds through the scheme of Competence Research BLU Unsoed No : 1248/UN23.14/PN.01.00/ 2017, February 3, 2017.

\section{REFERENCES}

Anisah, N., Rokhmani, R., \& Riwidiharso, E. (2017). Intensitas dan Variasi Morfometrik Trichodina sp. pada Benih Ikan Gurami (Osphronemus gouramy Lacepede) Pendederan I yang Dijual di Pasar Ikan Purwonegoro Kabupaten Banjarnegara. Majalah Ilmiah Biologi BIOSFERA: A Scientific Journal, 33(3), 134-141.

Basson, L., \& Van As, J. G. (1994). Trichodinid ectoparasites (Ciliophora: Peritrichida) of wild and cultured freshwater fishes in Taiwan, with notes on their origin. Systematic Parasitology, 28(3), 197-222.

Dana, D., Sumawidjaja, K., \& Hadiroseyani, Y. (2007). Trichodinid (Ciliophora: Peritrichida) Ectoparasites of Sand Goby (Oxyeleotris marmorata) Fry. Jurnal Akuakultur Indonesia, 1(1), 7-13.

Durborow, R. M. (2003). Protozoan Parasites. SRAC Publication. No. 4701. Fisheries and Marine Office in Central Java, 2013 Statistika Annual Report Of Fisheries And Marine Service. Central Java Province Semarang

Martins, M. L., Marchiori, N., Nunes, G., \& Rodrigues, M. P. (2010). First record of Trichodina heterodentata (Ciliophora: Trichodinidae) from chan- nel catfish, Ictalurus punctatus cultivated in Brazil. Brazilian Journal of Biology, 70(3), 637-644.

Martins, M. L., Marchiori, N., Roumbedakis, K., \& Lami, F. (2012). Trichodina nobilis Chen, 1963 and Trichodina reticulata Hirschmann et Partsch, 1955 from ornamental freshwater fishes in Brazil. Brazilian Journal of Biology, 72(2), 281286.

Nuryanto, A., Pramono, H., \& Sastranegara, M. H. (2017). Molecular Identification of Fish Larvae from East Plawangan of Segara Anakan, Cilacap, Central Java, Indonesia. Biosaintifika: Journal of Biology \& Biology Education, 9(1), 3340.

Rokhmani, E., Purwonohadi \& Khasanah, S. (2015). Hubungan Kekerabatan protozoa Trichodina sp yang menginfeksi benih gurame dari sentra pembenihan di Jawa Tengah dan Pengendaliannya. Proseding Semnas-LPPM 5, Unsoed Purwokerto

Rokhmani, E., Riwidiharso, Ariyani, E., Darsono \& Daniel, D. W., (2017). Hubungan Kekerabatan protozoa Trichodina sp yang menginfeksi benih gurame dari sentra pembenihan diBantul Jogyakarta. Proseding Sem. Nas Masy. Biodiv. Indonesia.

Rustikawati, I., Rostika, R., Iriana, D., \& Herlina, E. (2004). Intensitas Dan Prevalensi Ektoparasit Pada Benih Ikan Mas (Cyprinus carpio L.) Yang Berasal Dari Kolam Tradisional Dan Longyam Di Desa Sukamulya Kecamatan Singaparna Kabupaten Tasikmalaya. Jurnal Akuakultur Indonesia, 3(1), 33-39.

Tang, F., \& Zhao, Y. (2011). Study of trichodinids (Protozoa, Ciliophora) parasitic on gills of freshwater fishes from Chongqing, China, and identification of a new species Trichodina cyprinocola sp. nov. African journal of microbiology research, 5(30), 5523-5527.

Tang, F. H., Zhao, Y. J., \& Warren, A. (2013). Phylogenetic analyses of trichodinids (Ciliophora, Oligohymenophora) inferred from 18S rRNA gene sequence data. Current microbiology, 66(3), 306-313.

Utami, S. T. (2015). Prevalensi dan Variasi Morfometrik Trichodina sp. pada Benih Ikan Gurami (Osphronemus gourami Lac.) Pendederan I Milik Petani ikan Desa Luwung Rakit Banjarnegara Proseding Semnas MIPA UT Tanggerang

Windarto, R., Adiputra, Y. T., \& Efendi, E. (2013). Keragaman karakter morfologi antara Trichodina nobilis dan Trichodina reticulata pada ikan komet (Carrasius auratus). e-Jurnal Rekayasa dan Teknologi Budidaya Perairan, 1(2), 117-126.

Woo, P. T. K. (1995). Fish Disease and Disorders. Vol 1. Protozoa and Metazoan Infection. University of Guelph, Canada.

Zhao, Y. J., \& Tang, F. H. (2011). Taxonomic study on trichodinids (Protozoa, Ciliophora) infecting on gills of freshwater fishes, Cyprinus carpio and Mylopharyngodon piceus from China, with the description of Trichodina regularis sp. nov. European J. Scientific Research, 58(2), 231-237. 